\title{
Mechanisms Affecting the Acquisition, Persistence and Transmission of Francisella tularensis in Ticks
}

\author{
Brenden G. Tully and Jason F. Huntley * \\ Department of Medical Microbiology and Immunology, University of Toledo College of Medicine and Life \\ Sciences, Toledo, OH 43614, USA; Brenden.Tully@rockets.utoledo.edu \\ * Correspondence: Jason.Huntley@UToledo.edu
}

Received: 29 September 2020; Accepted: 21 October 2020; Published: 23 October 2020

\begin{abstract}
Over 600,000 vector-borne disease cases were reported in the United States (U.S.) in the past 13 years, of which more than three-quarters were tick-borne diseases. Although Lyme disease accounts for the majority of tick-borne disease cases in the U.S., tularemia cases have been increasing over the past decade, with $>220$ cases reported yearly. However, when comparing Borrelia burgdorferi (causative agent of Lyme disease) and Francisella tularensis (causative agent of tularemia), the low infectious dose $(<10$ bacteria), high morbidity and mortality rates, and potential transmission of tularemia by multiple tick vectors have raised national concerns about future tularemia outbreaks. Despite these concerns, little is known about how F. tularensis is acquired by, persists in, or is transmitted by ticks. Moreover, the role of one or more tick vectors in transmitting $F$. tularensis to humans remains a major question. Finally, virtually no studies have examined how $F$. tularensis adapts to life in the tick (vs. the mammalian host), how tick endosymbionts affect $F$. tularensis infections, or whether other factors (e.g., tick immunity) impact the ability of $F$. tularensis to infect ticks. This review will assess our current understanding of each of these issues and will offer a framework for future studies, which could help us better understand tularemia and other tick-borne diseases.
\end{abstract}

Keywords: Francisella tularensis; tularemia; tick-borne disease

\section{Introduction}

The most recent data from the United States (U.S.) Centers for Disease Control and Prevention (CDC) indicate that the reported number of tick-borne disease cases have more than doubled in the past 13 years and account for $77 \%$ of all vector-borne disease cases [1]. Although insecticides historically have been useful for controlling tick-borne diseases, resistance is becoming widespread in the U.S. [1,2]. Tick-borne diseases, including Lyme disease, spotted fever rickettsioses, babesiosis, anaplasmosis/ehrlichiosis, and tularemia, have been difficult to control because vaccines are not available. Additionally, reports of tick geographic range expansion and increases in wildlife populations that support ticks further complicate tick-borne disease control efforts [3-5]. Although Lyme disease accounted for $82 \%$ of all U.S. tick-borne disease cases between 2004 and 2016, tularemia cases have seen a resurgence in recent decades. Over 225 tularemia cases per year have been reported since 2015, with 314 reported cases in 2015-the most recorded since 1964 [1].

Francisella tularensis, the causative agent of tularemia, has been classified as a Tier 1 Select Agent by the CDC because of its low infectious dose, ease of aerosolization, rapid onset of severe disease, and high morbidity and mortality rates. Two $F$. tularensis subspecies cause human disease and, although they are closely related genetically, vary in their infectious dose and disease severity [6]. F. tularensis subsp. tularensis (Type A) has an extremely low infectious dose $(<10 \mathrm{CFU})$ and is associated with severe, often lethal, disease. F. tularensis subsp. holarctica (Type B), has a slightly higher infectious dose ( $>100 \mathrm{CFU})$ and is associated with progressive disease with lower mortality rates [7]. Type A F. tularensis is further 
divided into three distinct clades, A1a, A1b and A2. Previous studies have shown that mice infected with A1b die earlier than those infected with A1a, A2 or Type B F. tularensis strains, demonstrating marked differences in F. tularensis virulence [6]. Through repeated subculturing of F. tularensis subsp. holarctica, a live attenuated strain was created by the former Soviet Union in the 1930s and has been designated as the live vaccine strain (LVS) [8]. Despite its name, LVS is not a licensed vaccine in the U.S. due to the unresolved questions about the mechanism(s) of attenuation, adverse effects in some immunized humans, and incomplete protection against Type A aerosol infection [7,8]. However, LVS has been proven to be a useful tool to study F. tularensis virulence, as it causes lethal disease in mice yet can be worked with using normal biosafety precautions (i.e., biosafety level 2; BSL2) [9]. A separate Francisella species, F. novicida, rarely associated with disease in immunocompromised humans, is used as a surrogate for F. tularensis in some studies because of reduced biosafety requirements and ease of genetic manipulation [10].

Beyond concerns over the potential use of F. tularensis as a bioweapon (i.e., Select Agent designation), approximately half of tularemia cases in the U.S. are associated with tick bites [11,12]. In contrast, European tularemia cases are generally associated with ingestion of contaminated water from wells, streams, rivers, ponds, and lakes $[13,14]$. However, in Sweden, most tularemia cases are associated with mosquito bites [15-17]. A recently-published model indicated that climate change may triple the number of European tularemia cases per year, due to increases in mosquitos, higher temperatures, and increased precipitation [18]. Although ticks are generally not considered to be major drivers of European tularemia infections, F. tularensis-infected ticks have been reported in Spain [19], Germany [20], Denmark [21] and Poland [22,23]. Conversely, other groups have not detected F. tularensis in ticks collected from Poland, France, or the Netherlands [24-26], suggesting that more studies are needed to understand the current and future risks of tick-transmitted tularemia in Europe.

In the U.S., where tularemia was first documented, field-collected Dermacentor andersoni ticks (Rocky Mountain wood tick) were shown to transmit lethal Bacterium tularense (now known as F. tularensis) to guinea pigs [27]. However, the true role of D. andersoni ticks in U.S. tularemia cases remains unknown. Data from the CDC indicate that U.S. tularemia infections more commonly stem from D. variabilis (American dog tick) and Amblyomma americanum (Lone star tick) ticks, which are known to vary in their geographic distribution and mammalian hosts, as well as less understood factors, including tick physiology, endosymbionts, and antimicrobial defenses [4,28]. Indeed, previous studies have reported that differences in the numbers of tick phagocytic cells and prevalence/type of endosymbionts in A. americanum, D. andersoni, and D. variabilis ticks affected the molting success (i.e., survival between tick life stages) of these three tick species [29-31].

The complex life cycle of the tick (3 year progression from larvae to nymph to adult), including taking a blood meal from various hosts and molting to the next life stage after each blood meal, combined with varying lengths and severities of North American winters, indicates that upon infecting a tick, F. tularensis must undergo major changes over the course of $>5$ months to persist and replicate, before being transmitted to naive mammals. Laboratory experiments have confirmed that $F$. tularensis persists in ticks for $>4$ months, supporting the role of the tick as a potential environmental reservoir [32,33]. Additionally, F. tularensis has been shown to persist in ticks between molts (transstadial transmission) and replicate to high bacterial numbers in ticks, demonstrating that ticks serve as both a reservoir and an amplification vessel for F. tularensis in the environment $[33,34]$. Rabbits also have been implicated as a major environmental reservoir for tularemia, as studies have demonstrated that they can survive for 3-13 days following intradermal infection (mimicking a tick infection) with Type A1a, A1b or A2 F. tularensis and over 14 days for Type B F. tularensis infection [35]. This rabbit infection data, together with the 3-7 days that both $D$. variabilis and A. americanum ticks (varies depending on the tick life stage) take a blood meal, suggest that infected rabbits can potentially infect large numbers of ticks $[4,33,34]$. Despite those studies, we still do not understand whether different tick species acquire different levels of F. tularensis infections from different hosts, whether different tick species promote or 
restrict F. tularensis infections, what F. tularensis-tick interactions occur, how F. tularensis is maintained through the tick molt, or how infected ticks transmit $F$. tularensis to naïve hosts.

This review will highlight what is known about U.S. tick species that are associated with tularemia, factors that appear to promote F. tularensis infections in ticks, and how F. tularensis infections are maintained in ticks. This review also will highlight research areas where new or additional research studies are needed, including studies to elucidate F. tularensis-tick interactions, primary tick vectors for F. tularensis, mechanisms influencing F. tularensis infections of ticks, the ability of F. tularensis to persist in ticks, and mechanisms that promote F. tularensis transmission by ticks.

\section{Epidemiology of F. tularensis Transmission by Ticks in the U.S.}

Tularemia has been shown to be transmitted by at least four different ticks in the U.S., including D. variabilis, D. andersoni, D. occidentalis (Pacific coast tick), and A. americanum [27,33,34,36]. Although $D$. variabilis has been implicated as the primary vector, and A. americanum also appears to be an important vector for tularemia, we still do not know which tick(s) poses the greatest threat to human health in the U.S. [33,37]. A 1924 study noted that D. andersoni ticks could transmit virulent F. tularensis to guinea pigs [27] and a more recent study reported that $D$. andersoni ticks could be infected by and transmit F. novicida (rare infection of immunocompromised humans) [38]. However, very little is known about current infection rates of $D$. variabilis, A. americanum, or D. andersoni ticks with virulent strains of F. tularensis or about which ticks are commonly associated with current human tularemia cases. These, and other gaps in knowledge, have resulted in a call for new research studies on tick-borne F. tularensis [28]. In addition, although very few studies have explored F. tularensis-tick interactions, such studies could provide important information that could be used to develop new strategies to reduce $F$. tularensis in the environment [12].

One area of the U.S. that has been extensively studied to understand F. tularensis environmental persistence and tick transmission is Martha's Vineyard. In both 1978 and 2000, two separate tularemia outbreaks occurred on Martha's Vineyard, each involving 15 patients, with 1 fatality [39,40]. Although pneumonic disease was the most common symptom in both outbreaks, D. variabilis tick bites remain the only proven mode of transmission in most cases [41]. Sampling studies at Martha's Vineyard have assessed F. tularensis infection rates in D. variabilis ticks, finding a median annual prevalence of $3.4 \%$ over four years, suggesting that F. tularensis infections are stable on the island [42]. Additionally, D. variabilis ticks infected with Type A F. tularensis have been reported to harbor over $10^{8}$ genome equivalents/tick. Although genome equivalents may not accurately quantitate viable bacteria, those data indicate that $D$. variabilis ticks may sustain high $F$. tularensis numbers that cause significant transmission and disease in humans $[37,43]$.

The majority of tularemia cases occur in the south-central U.S. [33,42,44]. In fact, four states accounted for 58\% of tularemia cases in 2018 (most recent data from the CDC): Arkansas (24\%), Oklahoma (19\%), Kansas (8\%) and Missouri (7\%) [45]. In this region of the U.S., two major tick species exist: D. variabilis and A. americanum $[46,47]$. In one study from Missouri, $>8500$ A. americanum ticks were harvested over three years from various hosts, including white-tailed deer, fox, opossum and rabbits, with tick prevalence rates on these potential hosts ranging from $0.7 \%$ to $100 \%$. Although the presence and absence of pathogenic bacteria were not assessed in these A. americanum ticks, >1100 A. americanum nymphs were collected from a single rabbit, a natural reservoir for tularemia, highlighting the ability of one infected host to spread tularemia to thousands of other hosts, including humans [48]. In Arkansas, approx. $92 \%$ of field-collected ticks were A. americanum and approx. $7 \%$ were D. variabilis. Interestingly, none of the D. variabilis ticks tested positive for F. tularensis ( $>2000$ ticks tested), whereas approx. $4 \%$ of $A$. americanum ticks (>5000 ticks tested) were positive for F. tularensis [49]. A study of over 3500 field-collected D. variabilis ticks from Minnesota identified Type A F. tularensis in $3.6 \%$ of those ticks [50]. That infection rate was similar to what has been reported at Martha's Vineyard, where the annual F. tularensis infection rates in D. variabilis ticks ranges from $2.7 \%$ to $4.3 \%$, demonstrating that tick-borne tularemia infections are not restricted to the south-central U.S. [42]. In contrast, sampling 
studies in Washington state did not identify F. tularensis in either D. andersoni or D. variabilis ticks. However, that study examined less than 200 Dermacentor sp. ticks and only 25 tularemia cases were reported in Washington state between 2011 and 2016 [51]. Clearly, more studies are needed to assess F. tularensis infection rates in multiple tick vectors across the U.S. Further, given the geographic range expansion of various ticks throughout the U.S. [4], continuing studies will be needed to understand how this expansion will affect tick-borne disease transmission.

Although this review is focused on F. tularensis infections of ticks, historical data suggest that biting flies also can transmit tularemia [52,53]. However, no recent data from the CDC have linked tularemia infections with biting flies. One study used Drosophila as an arthropod model for F. tularensis infections, finding that doses as low as 200 CFU killed $>90 \%$ of fruit flies injected with F. tularensis LVS [54], bringing into question whether flies play a significant role in tularemia transmission.

\section{Factors that Affect F. tularensis Infections of Ticks}

Tick-borne pathogens must be able to efficiently transition from mammalian to arthropod hosts following tick feeding $[55,56]$. F. tularensis has been reported to infect and cause disease in over 300 animal species, including humans, highlighting the zoonotic potential and plasticity of F. tularensis [57]. Although not well studied, F. tularensis likely undergoes substantial changes, including major changes in protein expression profiles, between the mammalian host and the tick vector. Factors such as temperature and $\mathrm{pH}$ have been shown to be important cues when Borrelia burgdorferi, the causative agent of Lyme disease, transitions between mammalian hosts and ticks. These stimuli result in modifications of bacterial surface proteins to enhance B. burgdorferi acquisition by ticks [58,59]. Two surface-exposed lipoproteins, OspA and OspC, are among the most well-characterized proteins that are differentially expressed in B. burgdorferi. OspA is highly expressed under conditions that resemble the tick environment $\left(\mathrm{pH} 7.5\right.$ and $23^{\circ} \mathrm{C}$ ) [60]. Conversely, during a tick blood meal, the $\mathrm{pH}$ and temperature of the tick midgut change to 6.8 and $35^{\circ} \mathrm{C}$, respectively, triggering the upregulation of OspC, and promoting the migration of B. burgdorferi through the tick salivary gland to the mammalian host $[61,62]$.

In mammals, F. tularensis is an intracellular pathogen, infecting cell types ranging from macrophages, to neutrophils, to epithelial cells, to erythrocytes [63]. Many previous studies have identified F. tularensis virulence factors and have examined F. tularensis pathogenesis mechanisms using macrophage infection models [64]. When comparing macrophages and ticks, F. tularensis encounters low $\mathrm{pH}$ in both the macrophage phagosome and tick midgut $[62,65]$. In fact, both Type A F. tularensis and LVS are resistant to acid stress and viable at $\mathrm{pH} 3$ [66]. While it has been reported that F. tularensis responds to low $\mathrm{pH}$ by upregulating genes in the Francisella pathogenicity island (FPI) to escape from the phagosome $[67,68]$, we are not aware of any study that directly examines whether F. tularensis uses low $\mathrm{pH}$ as an indicator of the transition between mammalian and arthropod hosts.

Conversely, because iron is extremely limited in the macrophage phagosome but is readily available in replete ticks (through hemolysis), it is possible that F. tularensis may successfully transition from mammalian to arthropod hosts by sensing changes in iron and/or altering expression of iron-regulated genes in the tick (Figure 1) [69]. Iron-regulated genes have been shown to be important for the regulation of virulence in B. burgdorferi [70]. One study found that F. tularensis LVS differentially regulated over 70 genes in iron-limiting conditions, many of which were shown to be associated with virulence or intracellular replication [71]. Although that study did not explore F. tularensis gene regulation under iron-replete or high-iron conditions, similar to the tick midgut after a blood meal, such data could provide important information about how F. tularensis initially responds and adapts to life inside a tick. 


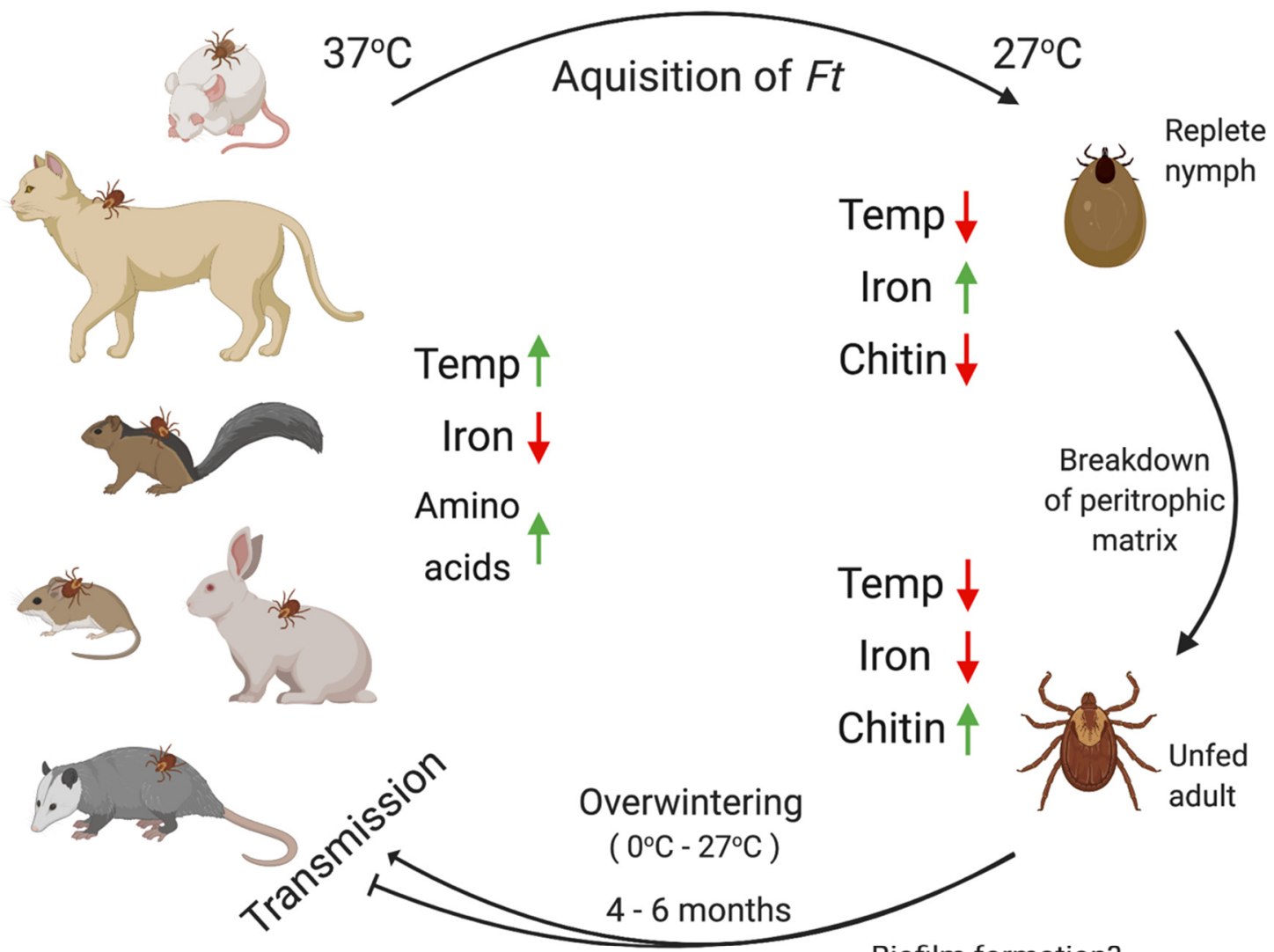

Biofilm formation?

\section{Endosymbionts: \\ - Provide nutrients to Ft? \\ - Sequester nutrients from $F t$ ?}

\author{
Tick Immune System: \\ - Restrict Ft infection? \\ - Does Ft modulate/supress?
}

Figure 1. Possible factors affecting F. tularensis infection, persistence, and transmission in ticks. Ticks acquire $F$. tularensis $(F t)$ by taking a blood meal from an infected host (e.g., mouse, cat, squirrel, vole, rabbit, or opossum). Upon infecting ticks, F. tularensis likely regulates gene expression based on changes in temperature ( 37 to $27^{\circ} \mathrm{C}$ ) and iron (low to high). Following processing of the blood meal, nutrients are likely limited in the tick. However, during the tick molting process, chitin fragments may be made available via chitin remodeling and/or breakdown of the peritrophic matrix. Subsequently, F. tularensis must overwinter in ticks, a process which may require biofilm formation, evasion/modulation of the tick immune system, and/or interactions with tick endosymbionts. However, previous studies have not examined any of these factors. Upon transmission from infected ticks to a new mammalian host, F. tularensis likely senses mammalian cues (e.g., increased temperature, low iron, higher concentrations of amino acids) and may alter its gene expression, including virulence genes, to promote infection. Figure created using Biorender.com.

A third environmental cue that F. tularensis might use to successfully transition to ticks may be temperature changes (Figure 1). One study reported that $11 \%$ of the F. tularensis LVS genome was differentially regulated when the bacterium was switched from ambient $\left(26^{\circ} \mathrm{C}\right)$ to mammalian $\left(37^{\circ} \mathrm{C}\right.$ ) temperature. Up to $40 \%$ of those identified genes were known to be important for virulence or intracellular replication, suggesting that temperature changes prime $F$. tularensis for pathogenicity in mammals [72]. Although that study may have provided information relevant to $F$. tularensis transmission from ticks to mammals, no studies have been performed to identify F. tularensis genes differentially regulated when transitioning from mammals to ticks. Another study found that $F$. tularensis modifies its lipopolysaccharide (LPS) structure in response to temperature changes, including altering expression 
of acetyltransferases, which add shorter or longer acyl chains to lipid A under ambient $\left(18^{\circ} \mathrm{C}\right)$ or mammalian $\left(37^{\circ} \mathrm{C}\right)$ temperatures, respectively [73]. Those LPS modifications were shown to promote bacterial survival and growth in cold conditions, which could be speculated to help F. tularensis survive and persist in ticks during the winter. However, experiments to confirm whether these LPS modifications promote $F$. tularensis persistence in ticks have not been conducted.

Likely because of the difficulties and biosafety risks of working with infected ticks, tick cell lines offer a simplified tool to understand how variables, such as temperature and tick species, can affect bacterial infection and persistence in arthropods. In one study, cell lines derived from $D$. andersoni and Ixodes scapularis ticks were infected with F. novicida, finding that at $34^{\circ} \mathrm{C}$, F. novicida infected and replicated 2-logs higher in D. andersoni-derived cells, compared to I. scapularis-derived cells. However, F. novicida infection killed up to $25 \%$ of $D$. andersoni cells, compared to I. scapularis cells that appeared to be unaffected by F. novicida up to 6 days post-infection. At $24^{\circ} \mathrm{C}$, F. novicida infected and replicated to similar levels in D. andersoni-derived cells, compared to I. scapularis-derived cells. However, approximately $15 \%$ less $D$. andersoni cell death was detected at the lower temperature, despite elevated bacterial numbers, indicating that low temperatures may decrease bacterial virulence, while still supporting bacterial replication in tick cells [5]. Although the above highlighted studies provided important insights into how F. tularensis may sense environmental cues and promote tick infections, there are still major gaps in our understanding of how virulent $F$. tularensis strains infect ticks, how F. tularensis adapts to life in the tick, and which ticks pose the greatest risk for tularemia transmission.

\section{F. tularensis Persistence and Transmission in Ticks}

As highlighted above, F. novicida was better able to infect and persist in D. andersoni-derived cells, compared with I. scapularis-derived cells [5]. Lower numbers of F. novicida in I. scapularis-derived cells may have been due to a wide range of factors, including decreased availability of nutrients (i.e., nutritional immunity) or inability of F. novicida to evade tick defense mechanisms [5]. However, limitations of those studies included the short time frame examined (i.e., $120 \mathrm{~h}$ ), use of a non-human pathogen, and use of cell lines that are unlikely to mimic the complex processes required for a tick infection. As is true for many tick-borne pathogens, future studies should carefully examine acquisition of the pathogen from an infected mammalian host to the tick vector, pathogen persistence through the molt and/or winter, migration of the pathogen through the tick salivary glands or regurgitation of the pathogen from the tick midgut, and pathogen infection of a mammalian host following a tick blood meal $[61,74]$.

Although the tick blood meal provides a nutrient-rich environment for many pathogens, these resources are depleted/digested within a few weeks [75] (Figure 1). As a result, long-term nutrient acquisition by pathogens in ticks becomes a major restriction. The minimum growth requirements of F. tularensis are well known, including iron, cysteine, and at least 12 other amino acids [76]. However, it is unclear how F. tularensis acquires such nutrients in the tick, particularly after the blood meal has been digested. Another consideration is that the tick blood digestion process generates harmful intermediates/breakdown products that damage microbes [77]. Although F. tularensis has been reported to encode a number of enzymes that protect the bacterium from free radical/reactive oxygen species damage [78,79], the role of these enzymes in protecting $F$. tularensis in the tick remains unstudied.

The majority of tick-borne bacterial pathogens, including Rickettsia rickettsii, Anaplasma phagocytophilum, Babesia microti, and even B. burgdorferi, replicate intracellularly within the tick. By infecting tick cells, such as the midgut epithelium, bacteria may avoid tick antimicrobial responses (e.g., defensins, lysozymes, microplusins) $[61,80,81]$ or toxic breakdown products from the tick blood meal $[82,83]$. With respect to $F$. tularensis, high bacterial numbers have been detected in $D$. variabilis midguts and hemolymph after taking a blood meal from mice, while limited bacterial numbers were detected in the tick salivary glands [34]. Avoiding the use of live vertebrate hosts, two separate studies utilized capillary tube feeding methods to infect either $D$. variabilis or A. americanum ticks with F. tularensis LVS. In those studies, F. tularensis LVS was detected in D. variabilis and A. americanum 
salivary glands and midguts. However, transmission to naïve hosts was not examined in either study $[33,84]$. While those studies indicated that both D. variabilis and A. americanum ticks could support F. tularensis infections as well as transstadial transmission [11,12], capillary feeding bypassed F. tularensis exposure to blood and immune cell molecules and failed to mimic numerous cues that F. tularensis likely encounters during the mammal to tick transition (Figure 1). Separate studies demonstrated that D. variabilis ticks could transmit Type A1b (strain MA00-2987), Type A2 (strain WY96-3418), and Type B (strain KY99-3387) F. tularensis infections with high efficiency (e.g., between $58 \%$ and $89 \%$ of naïve mice $(n=12-23)$ were infected) [37]. However, similar studies have not been performed using $A$. americanum ticks and the ability of virulent $F$. tularensis strains to infect and persist in these ticks is unknown.

\section{F. tularensis Biofilms}

Biofilm formation has been shown to enhance resistance to various stressors, including antimicrobials, hypoxia, and nutrient limitation [85-87]. In the case of Vibrio cholerae, biofilm formation on crab shells has been shown to be an important carbon source, contributing to bacterial persistence during the aquatic cycle [88]. Additionally, Yersinia pestis has been shown to form biofilms in fleas, which aids in persistence and transmission to mammalian hosts [89]. F. tularensis has been isolated from a range of environments, including arthropods [27,90,91]. Given that chitin is widely available in nature and is a major component of the tick cuticle [92], it has been speculated that chitin may promote F. tularensis biofilm formation and may serve as a carbon source for F. tularensis in ticks. However, the true role of biofilms in F. tularensis virulence and pathogenesis remains unclear (Figure 1) due to the fact that many biofilm studies have been performed using F. novicida, an opportunistic pathogen. Previous studies demonstrated that $F$. novicida rapidly forms robust biofilms on a variety of surfaces, including plastic, glass, and crab shells [93-95]. In contrast, although F. tularensis Type A and Type B strains also have been shown to form biofilms, those biofilms were less dense and formed at slower rates than F. novicida [93,96]. Given differences in in vitro biofilm formation among the three Francisella species/subspecies (F. novicida, Type A, and Type B) and unanswered questions about how F. tularensis persists in ticks, future studies should examine biofilm formation in ticks by virulent $F$. tularensis strains.

\section{F. tularensis Chitin Utilization}

One study reported that $F$. novicida requires two chitinases, chiA and $c h i B$, part of the same metabolic pathway, to use chitin as a sole carbon source and forms biofilms on chitin (crab shells) [93]. Conversely, another group demonstrated that, compared to wild-type F. novicida, chiA and chiB mutants produced more robust biofilms in negatively-charged tissue culture plates and these thicker biofilms were more resistant to the charged aminoglycoside antibiotic gentamicin, but not ciprofloxacin. Those results lead the authors to speculate that chitinases also may function by changing the surface charge of $F$. novicida, allowing for changes in surface attachment and biofilm formation [97]. Although only one study has examined chitinase mutants in ticks, all three F. novicida mutants (chiA, chiB, and chiAB) were detected in $D$. andersoni tick midguts and salivary glands 4 days after feeding on infected mice. However, given the short time frame of those studies and noted variations in bacterial detection in tick samples, it still is unclear whether chitinase genes are required for virulent $F$. tularensis to infect and persist in ticks [38].

During the tick molting process (i.e., larvae to nymph; nymph to adult), the tick cuticle, of which chitin is a major component, is degraded, remodeled, and new components are synthesized [98]. Chitin is a polymer of N-acetylglucosamine (GlcNAc) and it has been speculated that GlcNAc, and other chitin components, may be released during tick molting. The peritrophic matrix (Figure 1), a semipermeable chitinous membrane that surrounds the tick blood meal, also has been speculated to breakdown and remodel during tick molting [98]. Although little is known about how F. tularensis persists in ticks through the molting process or whether F. tularensis can utilize free chitin fragments liberated during tick molting, one previous study reported that $F$. tularensis numbers dramatically increased in D. variabilis ticks following the nymph-adult molt [34]. 


\section{Tick Endosymbionts}

Recent studies on tick microbiomes have raised questions regarding how various endosymbionts (symbiotic and usually non-pathogenic microbes) impact the ability of ticks to harbor pathogens [99]. Given that tick microbiota diversity appears to vary based on many factors, the acquisition, persistence, and transmission of tick-borne diseases may be directly impacted by differences in tick microbiota [31,99]. In addition to altering tick immune responses, bacterial endosymbionts have been shown to provide beneficial vitamins and nutrients for ticks, as well as any residing pathogens [99,100]. Although not associated with tularemia, the Gulf coast tick (Amblyomma maculatum) was reported to harbor a Francisella-like endosymbiont (FLE) that, despite undergoing genome reduction (i.e., one-third of coding genes, including virulence genes, were inactivated), gained the ability to synthesize cysteine, threonine and tyrosine. It is well-established that virulent $F$. tularensis strains are deficient in biosynthesis pathways for many amino acids, including cystine, threonine, and tyrosine [76], so it is interesting to speculate whether FLEs provide these amino acids to support $F$. tularensis infections in ticks.

Non-pathogenic Coxiella endosymbionts have been detected from Amblyomma sp., Dermacentor sp., Hyalomma sp., Ixodes sp., Ornithodoros sp., and Rhipicephalus sp. ticks. Rickettsia endosymbionts are common in Ixodes and some Ornithodoros tick species, while FLEs have been found in Amblyomma, Dermacentor, and Hyalomma ticks [31]. However, the number of different endosymbionts and prevalence of endosymbionts in each tick are known to vary by geographic location, time of year collected, life stage, sex, tick species, and lab-reared vs. wild-caught ticks [31,101-104]. A comprehensive study of over 80 tick species from around the world, including lab-reared and wild-caught ticks, identified the most prevalent tick endosymbiont to be a Coxiella-like endosymbiont (CLE) [31]. Although CLEs were thought to be evolutionarily stable in many tick species, further analysis showed that four other genera of endosymbionts, including Francisella, Rickettsiella, Rickettsia, and Spiroplasma, are slowly replacing CLEs as alternative obligate symbionts [31]. The presence of vitamin B2 and B7 synthesis pathways in FLEs, which are absent in CLEs, may explain why FLEs are becoming more common in several tick species, including Amblyomma, Dermacentor, and Hyalomma [31]. Although F. tularensis is known to infect these three tick genera, questions remain about how FLEs or other tick endosymbionts influence the ability of $F$. tularensis to infect, persist, and be transmitted by ticks $[33,34,105]$.

To answer such questions, one group examined how the tick microbiome influenced F. novicida infections of $D$. andersoni ticks. In those studies, field-collected $D$. andersoni ticks contained a mixture of an unknown Francisella sp. and a FLE. Those endosymbionts were disrupted by feeding D. andersoni ticks on antibiotic-treated hosts. When those same ticks were experimentally-infected with F. novicida, the ticks harbored 0.5-log less F. novicida compared to non-antibiotic treated D. andersoni ticks. Those results suggested that FLEs and non-pathogenic Francisella endosymbionts may promote infection and persistence by other Francisella sp. [99]. Separate studies have shown that the midguts of Amblyomma aureolatum ticks, not known to transmit $F$. tularensis, are dominated by FLEs. Given the presence of FLEs in those ticks, but absence of $F$. tularensis, that study demonstrated that ticks harboring FLEs will not necessarily become infected with, or transmit, tularemia [106]. Taken together, much remains to be learned about the true role of non-pathogenic Francisella sp., FLEs, and other tick endosymbionts in ticks commonly-associated with tularemia (e.g., D. variabilis and A. americanum) in promoting infections by pathogenic $F$. tularensis strains.

On Martha's Vineyard, and two other locations in Massachusetts, two distinct FLEs were reported in D. variabilis ticks. One FLE (designated as D. variabilis symbiont, DVS) was detected in $100 \%$ of ticks and a newly-identified FLE (designated as D. variabilis francisella, DVF; $96.6 \%$ similar to DVS) was detected in 55\% of those same ticks. While DVS was restricted to ovarian tissues and Malpighian tubules, DVF was found in the hemolymph, suggesting that salivary gland colonization also was possible [41]. Given the history of F. tularensis infections on Martha's Vineyard and high prevalence of DVS in these D. variabilis ticks $[40,41]$, it is interesting to speculate about whether one FLE has recently evolved, whether one FLE is replacing the other, and what role each FLE plays in tularemia transmission. 
Further studies examining FLE prevalence in ticks were conducted in southern Indiana, where two FLEs were identified in D. variabilis ticks. One FLE, accounting for over $75 \%$ of all identified microbes in D. variabilis, was present in $100 \%$ of ticks, and was identical to the DVS endosymbiont in D. variabilis ticks from Martha's Vineyard [41,107]. This finding indicates that the DVS endosymbiont is not limited to Martha's Vineyard and may colonize D. variabilis ticks across the country. A second FLE was detected in Indiana D. variabilis ticks, matching to the DVF endosymbiont in D. variabilis ticks from Martha's Vineyard [41,107]. DVF accounted for approx. 10\% of all tick microbiota sequences, suggesting that DVF is not an obligate endosymbiont. In Ontario, Canada, FLEs only were detected in $44 \%$ of $D$. variabilis ticks. However, those authors noted that their sequencing methods may not have been optimal for detecting low abundance organisms [108]. A more comprehensive study examined D. variabilis tick microbiomes from 26 U.S. states and five Canadian provinces, finding FLEs in only $24 \%$ of those ticks [109]. However, those authors also noted that a low abundance of endosymbiont DNA may have contributed to false negatives. Two phylogenetically-distinct FLE groups were identified in that study: one FLE group spanning the entire U.S. east of the Rockies (including most of southern Canada); and a second distinct FLE group present on the west coast of the U.S. Taken together, while much remains to be learned about the molecular mechanisms by which FLEs and endosymbionts support F. tularensis infections of $D$. variabilis (and other ticks), these studies do indicate that FLEs may play important roles in infection and transmission of F. tularensis by ticks [99].

Given that previous studies have demonstrated how differences in microbiomes alter tick competence for pathogen infections [99,110], more comprehensive studies are needed to examine tick microbiomes and understand how those microbiomes influence F. tularensis infections of ticks. Importantly, none of the above studies examined tick microbiomes from the south-central United States, where tularemia is most prevalent $[28,109]$, nor did they examine A. americanum tick microbiomes. Additionally, is it unclear how identified non-pathogenic Francisella sp. and/or FLEs differ in their abilities to act as tick endosymbionts or to promote F. tularensis infections. Clearly, more studies are needed to isolate and sequence these endosymbionts to answer these questions.

There are important practical applications of arthropod microbiome studies, as highlighted by the use of the bacterium Wolbachia to colonize and compete for resources with Dengue virus in mosquitos [111]. Similarly, mechanisms that alter the microbiota of ticks or reduce obligate endosymbionts (e.g., DVS) from ticks may decrease F. tularensis acquisition or persistence in the environment. As highlighted above, more studies are needed to better understand which ticks are capable of being infected by, harboring, and transmitting F. tularensis, to study the diversity of endosymbionts that colonize those tick vectors, and to examine how those tick endosymbionts promote infection, persistence, and transmission of tularemia (Figure 1). Finally, although some Rickettsia endosymbionts have been shown to cause transient inflammation in animals and humans [112,113], it still is not known whether non-pathogenic Francisella sp. or FLEs are pathogenic to animals or humans.

\section{The Tick Immune System and Antimicrobial Activities}

The tick immune system has both cell-mediated and humoral defense mechanisms [114-116]. Hemocytes in the tick hemocoel are the primary cells of the tick cell-mediated immune system, recognizing and clearing microbes using processes including nodulation (aggregation), encapsulation, and phagocytosis. D. variabilis hemocytes have been shown to quickly aggregate around Gram-positive and Gram-negative bacteria inside the tick hemocoel, forming nodule-like masses, followed by hemocyte encapsulation around bacteria $[117,118]$. At least three different types of hemocytes exist in D. variabilis, namely plasmatocytes, type-1 granulocytes, and type-2 granulocytes, which form a multilayered capsule around foreign objects [119]. While studies have not been performed to examine aggregation or encapsulation of F. tularensis in D. variabilis or A. americanum, it is interesting to note that descriptions of tick hemocyte encapsulation of bacteria, including formation of a necrotic core in the center of these nodule-like masses, resemble descriptions of granuloma-like masses in F. tularensis-infected animals 
and humans [120-122]. D. variabilis hemocytes also have been shown to directly phagocytose and eliminate B. burgdorferi from infected ticks in $<24 \mathrm{~h}$ [123]. Conversely, hemocyte phagocytosis does not necessarily kill all bacteria, as A. phagocytophilum infection of I. scapularis hemocytes is required for migration of the pathogen from the midgut to tick salivary glands [124]. Similarly, R. parkeri, a member of the spotted fever group, was detected in A. americanum tick hemocytes $>1$ month after infection, providing further evidence that tick hemocytes may not clear all bacterial infections and suggesting that some bacteria may evade tick humoral immune responses by infecting hemocytes [125]. Parallel comparisons have been made to help explain why F. tularensis infects mammalian macrophages-to evade humoral immune responses (e.g., antibodies) and other host immune responses [126,127]. Clearly, studies are needed to examine how D. variabilis and A. americanum (and potentially other ticks) hemocytes interact with F. tularensis and whether F. tularensis infects tick hemocytes to evade extracellular immune responses.

The tick humoral immune system includes extracellular effector molecules, such as lectins, complement-related molecules, and antimicrobial peptides [114-116]. The sequencing and annotation of the I. scapularis genome revealed a large number of putative genes that may protect ticks from microbial infections including defensins, lysozyme, peptidoglycan-recognizing proteins, and other putative antimicrobial peptides [128]. Defensins are small (4-6 kDa) cationic peptides that are active against Gram-negative and Gram-positive pathogens by attaching to and inserting in membranes, then forming pores [129]. D. variabilis has been shown to express a number of antimicrobial peptides, including defensin-1, defensin-2, lysozyme, and kunitz-type serine protease inhibitor, that limit infection by R. montanensis, another member of the spotted fever group [130-132]. Another D. variabilis defensin, varisin (5.3 kDa peptide), was reported to work together with lysozyme to lyse B. burgdorferi [133]. Conversely, depletion of varisin from D. variabilis ticks reduced Anaplasma marginale infections, suggesting that the true role of defensins in tick-pathogen interactions may be complex [134,135]. A recent proteomic analysis of $A$. americanum tick proteins produced during a blood meal indicates that this tick species produces at least six antimicrobial peptides, including kunitz-type serine proteinase inhibitor, lipochalin, microplusin, lysozyme, and defensins [136]. Many other potential tick immune molecules, such as fibrinogen-related proteins (FREPs) and thioester-containing proteins (TEPs), have been identified in soft and hard ticks and have been proposed to play important roles in protecting ticks from microbial infections [114-116]. However, the expression of these lesser-known molecules in either D. variabilis or A. americanum ticks has not been examined and their antibacterial effects on F. tularensis is unknown. In summary, although a great deal has been learned about the tick immune system, this field is rapidly evolving, and new mechanisms of tick cellular and humoral immunity are likely to be discovered at a rapid pace. Given the lack of previous studies to compare/contrast how D. variabilis and A. americanum immune systems respond to F. tularensis infections and recent expansion of high-throughput discovery approaches in ticks (e.g., genomics, proteomics, metabolomics) [115], future studies should examine how different tick vectors respond to F. tularensis infections. Such information could help explain why ticks such as D. variabilis and A. americanum harbor and transmit F. tularensis.

\section{Conclusions}

Despite a number of excellent studies that have examined F. tularensis (or F. novicida) in different tick vectors, we still do not understand: (1) how F. tularensis responds to the dramatic shift from mammals to ticks (e.g., temperature, iron concentration, and chitin); (2) how F. tularensis persists in ticks for months (e.g., Does F. tularensis infect/invade tick cells? Does F. tularensis migrate to/colonize salivary glands?); (3) how F. tularensis is transmitted from infected ticks to naïve hosts (e.g., Does F. tularensis actively sense and respond to a blood meal to promote transmission?); and (4) which tick(s) or arthropod vectors pose the greatest threat for transmitting tularemia to humans.

Although a wealth of information is available regarding B. burgdorferi genes/proteins that contribute to infection, persistence, and transmission by I. scapularis ticks, little is known about F. tularensis 
genes/proteins that confer similar functions. In fact, only one study has examined the role of $F$. tularensis genes in ticks. In those studies, F. tularensis purMCD was not found to be important for infection of ticks [34]. Based on previous studies that have identified specific genes/proteins required for a given tick-borne pathogen to infect its tick vector, similar or homologous F. tularensis genes/proteins would be obvious targets. However, given the unusual nature of the F. tularensis genome [137], other gene targeting strategies may be needed (e.g., F. tularensis transposon library screening in ticks; transcriptional analysis of $F$. tularensis in ticks). In addition, despite the availability of a number of tick cell lines and avirulent $F$. tularensis strains, future studies should examine how virulent $F$. tularensis strains successfully infect ticks, how $F$. tularensis survives the toxic process of blood digestion in a tick, how $F$. tularensis persists in ticks for months (i.e., overwintering) with very limited nutrients, how ticks respond to F. tularensis infections (e.g., tick antimicrobial responses), how F. tularensis responds to or actively modulates tick responses (e.g., bacterial immunomodulatory molecules), and how F. tularensis is transmitted to naïve hosts by infected ticks (including comparing transmission efficiency by different ticks, comparing host immune responses to $F$. tularensis infection by different ticks, and comparing disease progression after transmission by different ticks).

As outlined above and in Figure 1, there are many factors which may influence F. tularensis infections of ticks. To initially establish infections of ticks, F. tularensis may sense changes in temperature and iron levels. Although the tick blood meal is replete with nutrients, harmful breakdown products (e.g., ROS and RNS) and excess iron may damage F. tularensis. Tick immune responses and/or antimicrobial peptides may inhibit $F$. tularensis persistence and growth. Following blood meal processing, nutrients are likely extremely limited in the tick $[138,139]$. However, during tick molting, chitin fragments and components of the peritrophic matrix may be an important carbon source for F. tularensis. Some tick endosymbionts may provide nutrients to $F$. tularensis that aid in long-term persistence and replication. Conversely, other tick endosymbionts may compete with $F$. tularensis for nutrients or may stimulate tick antimicrobial defenses that restrict $F$. tularensis replication. All of these factors (Figure 1), and others, could impact the ability of $F$. tularensis to infect, persist, replicate, and be transmitted to naïve hosts. As such, these factors, and others not highlighted in this review, should be examined in future studies. All of the above highlighted studies are important, not only to better understand F. tularensis and to limit tularemia infections, but to provide information that is broadly-applicable to the tick-borne disease and vector-borne disease fields.

Author Contributions: Conceptualization, B.G.T. and J.F.H.; Software, B.G.T.; Validation, B.G.T. and J.F.H.; Formal Analysis, B.G.T. and J.F.H.; Data Curation, B.G.T. and J.F.H.; Writing-Original Draft Preparation, B.G.T. and J.F.H.; Writing-Review \& Editing, B.G.T. and J.F.H.; Supervision, J.F.H.; Project Administration, J.F.H.; Funding Acquisition, J.F.H. All authors have read and agreed to the published version of the manuscript.

Funding: This work was supported by grant R01 AI093351 from the National Institute of Allergy and Infectious Disease of the National Institutes of Health (NIAID-NIH) to J.F.H. and by bridge funding from the University of Toledo College of Medicine and Life Sciences to J.F.H.

Conflicts of Interest: The authors declare that the research was conducted in the absence of any commercial or financial relationships that could be construed as a potential conflict of interest.

\section{References}

1. Rosenberg, R.; Lindsey, N.P.; Fischer, M.; Gregory, C.J.; Hinckley, A.F.; Mead, P.S.; Paz-Bailey, G.; Waterman, S.H.; Drexler, N.A.; Kersh, G.J.; et al. Vital Signs: Trends in Reported Vectorborne Disease Cases United States and Territories, 2004-2016. Mmwr Morb. Mortal. Wkly. Rep. 2018, 67, 496-501. [CrossRef]

2. Ostfeld, R.S.; Canham, C.D.; Oggenfuss, K.; Winchcombe, R.J.; Keesing, F. Climate, deer, rodents, and acorns as determinants of variation in lyme-disease risk. PLoS Biol. 2006, 4, e145. [CrossRef]

3. Molaei, G.; Little, E.A.H.; Williams, S.C.; Stafford, K.C. Bracing for the Worst-Range Expansion of the Lone Star Tick in the Northeastern United States. N. Engl. J. Med. 2019, 381, 2189-2192. [CrossRef] [PubMed]

4. Sonenshine, D.E. Range Expansion of Tick Disease Vectors in North America: Implications for Spread of Tick-Borne Disease. Int. J. Environ. Res. Public Health 2018, 15, 478. [CrossRef] 
5. Reif, K.E.; Ujczo, J.K.; Alperin, D.C.; Noh, S.M. Francisella tularensis novicida infection competence differs in cell lines derived from United States populations of Dermacentor andersoni and Ixodes scapularis. Sci. Rep. 2018, 8, 12685. [CrossRef] [PubMed]

6. Molins, C.R.; Delorey, M.J.; Yockey, B.M.; Young, J.W.; Sheldon, S.W.; Reese, S.M.; Schriefer, M.E.; Petersen, J.M. Virulence differences among Francisella tularensis subsp. tularensis clades in mice. PLoS ONE 2010, 5, e10205. [CrossRef]

7. Ellis, J.; Oyston, P.C.; Green, M.; Titball, R.W. Tularemia. Clin. Microbiol. Rev. 2002, 15, 631-646. [CrossRef] [PubMed]

8. Oyston, P.C.; Quarry, J.E. Tularemia vaccine: Past, present and future. Antonie Van Leeuwenhoek 2005, 87, 277-281. [PubMed]

9. Eigelsbach, H.T.; Downs, C.M. Prophylactic effectiveness of live and killed tularemia vaccines. I. Production of vaccine and evaluation in the white mouse and guinea pig. J. Immunol. 1961, 87, 415-425.

10. Kingry, L.C.; Petersen, J.M. Comparative review of Francisella tularensis and Francisella novicida. Front. Cell. Infect. Microbiol. 2014, 4, 35. [CrossRef] [PubMed]

11. Dennis, D.T.; Inglesby, T.V.; Henderson, D.A.; Bartlett, J.G.; Ascher, M.S.; Eitzen, E.; Fine, A.D.; Friedlander, A.M.; Hauer, J.; Layton, M.; et al. Tularemia as a biological weapon: Medical and public health management. JAMA 2001, 285, 2763-2773. [CrossRef] [PubMed]

12. Zellner, B.; Huntley, J.F. Ticks and Tularemia: Do We Know What We Don't Know? Front. Cell. Infect. Microbiol. 2019, 9, 146. [CrossRef] [PubMed]

13. Larssen, K.W.; Bergh, K.; Heier, B.T.; Vold, L.; Afset, J.E. All-time high tularaemia incidence in Norway in 2011: Report from the national surveillance. Eur. J. Clin. Microbiol. Infect. Dis. 2014, 33, 1919-1926. [CrossRef]

14. Hennebique, A.; Boisset, S.; Maurin, M. Tularemia as a waterborne disease: A review. Emerg. Microbes Infect. 2019, 8, 1027-1042. [CrossRef] [PubMed]

15. Dryselius, R.; Hjertqvist, M.; Makitalo, S.; Lindblom, A.; Lilja, T.; Eklof, D.; Lindstrom, A. Large outbreak of tularaemia, central Sweden, July to September 2019. Eurosurveillance 2019, 24. [CrossRef]

16. Ryden, P.; Bjork, R.; Schafer, M.L.; Lundstrom, J.O.; Petersen, B.; Lindblom, A.; Forsman, M.; Sjostedt, A.; Johansson, A. Outbreaks of tularemia in a boreal forest region depends on mosquito prevalence. J. Infect. Dis. 2012, 205, 297-304. [CrossRef]

17. Eliasson, H.; Broman, T.; Forsman, M.; Back, E. Tularemia: Current epidemiology and disease management. Infect. Dis. Clin. N. Am. 2006, 20, 289-311. [CrossRef]

18. Ma, Y.; Bring, A.; Kalantari, Z.; Destouni, G. Potential for Hydroclimatically Driven Shifts in Infectious Disease Outbreaks: The Case of Tularemia in High-Latitude Regions. Int. J. Environ. Res. Public Health 2019, 16, 3717. [CrossRef]

19. Lopes de Carvalho, I.; Toledo, A.; Carvalho, C.L.; Barandika, J.F.; Respicio-Kingry, L.B.; Garcia-Amil, C.; Garcia-Perez, A.L.; Olmeda, A.S.; Ze-Ze, L.; Petersen, J.M.; et al. Francisella species in ticks and animals, Iberian Peninsula. Ticks Tick Borne Dis. 2016, 7, 159-165. [CrossRef] [PubMed]

20. Appelt, S.; Koppen, K.; Radonic, A.; Drechsel, O.; Jacob, D.; Grunow, R.; Heuner, K. Genetic Diversity and Spatial Segregation of Francisella tularensis Subspecies holarctica in Germany. Front. Cell. Infect. Microbiol. 2019, 9, 376. [CrossRef] [PubMed]

21. Haulrig, M.B.; Mathiasen, G.; Nielsen, R.M.; Kromann, C.B.; Krogfelt, K.A.; Wiese, L. Two cases of tick-borne transmitted tularemia on Southern Zealand, Denmark. APMIS 2020, 128, 61-64. [CrossRef] [PubMed]

22. Wojcik-Fatla, A.; Zajac, V.; Sawczyn, A.; Cisak, E.; Sroka, J.; Dutkiewicz, J. Occurrence of Francisella spp. in Dermacentor reticulatus and Ixodes ricinus ticks collected in eastern Poland. Ticks Tick Borne Dis. 2015, 6, 253-257. [CrossRef] [PubMed]

23. Bielawska-Drozd, A.; Cieslik, P.; Zakowska, D.; Glowacka, P.; Wlizlo-Skowronek, B.; Zieba, P.; Zdun, A. Detection of Coxiella burnetii and Francisella tularensis in Tissues of Wild-living Animals and in Ticks of North-west Poland. Pol. J. Microbiol. 2018, 67, 529-534. [CrossRef] [PubMed]

24. Forminska, K.; Wolkowicz, T.; Brodzik, K.; Stefanoff, P.; Golab, E.; Masny, A.; Osiak, B.; Cieslik, P.; Bielawska-Drozd, A.; Zasada, A.A. Genetic diversity of Francisella tularensis in Poland with comments on MLVA genotyping and a proposition of a novel rapid v4-genotyping. Ticks Tick Borne Dis. 2020, 11, 101322. [CrossRef] 
25. Michelet, L.; Joncour, G.; Devillers, E.; Torina, A.; Vayssier-Taussat, M.; Bonnet, S.I.; Moutailler, S. Tick species, tick-borne pathogens and symbionts in an insular environment off the coast of Western France. Ticks Tick Borne Dis. 2016, 7, 1109-1115. [CrossRef] [PubMed]

26. Janse, I.; Maas, M.; Rijks, J.M.; Koene, M.; van der Plaats, R.Q.; Engelsma, M.; van der Tas, P.; Braks, M.; Stroo, A.; Notermans, D.W.; et al. Environmental surveillance during an outbreak of tularaemia in hares, the Netherlands, 2015. Eurosurveillance 2017, 22, 30607. [CrossRef]

27. Parker, R.R.; Spencer, R.R.; Francis, E. Tularæmia: XI. Tularæmia Infection in Ticks of the Species Dermacentor Andersoni Stiles in the Bitterroot Valley, Mont. Public Health Rep. (1896-1970) 1924, 39, 1057-1073. [CrossRef]

28. Eisen, L. A call for renewed research on tick-borne Francisella tularensis in the Arkansas-Missouri primary national focus of tularemia in humans. J. Med. Entomol. 2007, 44, 389-397. [CrossRef]

29. Nagamori, Y.; Payton, M.; Coburn, L.; Thomas, J.E.; Reichard, M. Nymphal engorgement weight predicts sex of adult Amblyomma americanum, Amblyomma maculatum, Dermacentor andersoni, Dermacentor variabilis, and Rhipicephalus sanguineus ticks. Exp. Appl. Acarol. 2019, 77, 401-410. [CrossRef]

30. Oliver, J.D.; Dusty Loy, J.; Parikh, G.; Bartholomay, L. Comparative analysis of hemocyte phagocytosis between six species of arthropods as measured by flow cytometry. J. Invertebr. Pathol. 2011, 108, 126-130. [CrossRef]

31. Duron, O.; Binetruy, F.; Noel, V.; Cremaschi, J.; McCoy, K.D.; Arnathau, C.; Plantard, O.; Goolsby, J.; Perez de Leon, A.A.; Heylen, D.J.A.; et al. Evolutionary changes in symbiont community structure in ticks. Mol. Ecol. 2017, 26, 2905-2921. [CrossRef]

32. Hopla, C.E. Experimental studies on tick transmission of tularemia organisms. Am. J. Hyg. 1953, 58, 101-118. [CrossRef] [PubMed]

33. Mani, R.J.; Metcalf, J.A.; Clinkenbeard, K.D. Amblyomma americanum as a Bridging Vector for Human Infection with Francisella tularensis. PLoS ONE 2015, 10, e0130513. [CrossRef] [PubMed]

34. Coburn, J.; Maier, T.; Casey, M.; Padmore, L.; Sato, H.; Frank, D.W. Reproducible and quantitative model of infection of Dermacentor variabilis with the live vaccine strain of Francisella tularensis. Appl. Environ. Microbiol. 2015, 81, 386-395. [CrossRef]

35. Brown, V.R.; Adney, D.R.; Bielefeldt-Ohmann, H.; Gordy, P.W.; Felix, T.A.; Olea-Popelka, F.J.; Bowen, R.A. Pathogenesis and Immune Responses of Francisella Tularensis Strains in Wild-Caught Cottontail Rabbits (Sylvilagus Spp.). J. Wildl. Dis. 2015, 51, 564-575. [CrossRef]

36. Parker, R.R.; Brooks, C.S.; Marsh, H. The Occurrence of Bacterium tularense in the Wood Tick, Dermacentor occidentalis, in California. Public Health Rep. (1896-1970) 1929, 44, 328-335. [CrossRef]

37. Reese, S.M.; Petersen, J.M.; Sheldon, S.W.; Dolan, M.C.; Dietrich, G.; Piesman, J.; Eisen, R.J. Transmission efficiency of Francisella tularensis by adult american dog ticks (Acari: Ixodidae). J. Med. Entomol. 2011, 48, 884-890. [CrossRef] [PubMed]

38. Reif, K.E.; Palmer, G.H.; Ueti, M.W.; Scoles, G.A.; Margolis, J.J.; Monack, D.M.; Noh, S.M. Dermacentor andersoni transmission of Francisella tularensis subsp. novicida reflects bacterial colonization, dissemination, and replication coordinated with tick feeding. Infect. Immun. 2011, 79, 4941-4946. [CrossRef] [PubMed]

39. Kugeler, K.J.; Mead, P.S.; Janusz, A.M.; Staples, J.E.; Kubota, K.A.; Chalcraft, L.G.; Petersen, J.M. Molecular Epidemiology of Francisella tularensis in the United States. Clin. Infect. Dis. 2009, 48, 863-870. [CrossRef] [PubMed]

40. Goethert, H.K.; Shani, I.; Telford, S.R., III. Genotypic diversity of Francisella tularensis infecting Dermacentor variabilis ticks on Martha's Vineyard, Massachusetts. J. Clin. Microbiol. 2004, 42, 4968-4973. [CrossRef]

41. Goethert, H.K.; Telford, S.R., III. A new Francisella (Beggiatiales: Francisellaceae) inquiline within Dermacentor variabilis say (Acari: Ixodidae). J. Med. Entomol. 2005, 42, 502-505. [CrossRef]

42. Goethert, H.K.; Telford, S.R., III. Nonrandom distribution of vector ticks (Dermacentor variabilis) infected by Francisella tularensis. PloS Pathog. 2009, 5, e1000319. [CrossRef]

43. Goethert, H.K.; Telford, S.R., III. Quantum of infection of Francisella tularensis tularensis in host-seeking Dermacentor variabilis. Ticks Tick Borne Dis. 2010, 1, 66-68. [CrossRef] [PubMed]

44. Montales, M.T.; Beebe, A.; Chaudhury, A.; Haselow, D.; Patil, S.; Weinstein, S.; Taffner, R.; Patil, N. A Clinical Review of Tick-Borne Diseases in Arkansas. J. Ark. Med. Soc. 2016, 112, 254-258. [PubMed]

45. Centers for Disease Control and Prevention: Tularemia: Statistics. Available online: https://www.cdc.gov/ tularemia/statistics/index.html (accessed on 23 September 2020). 
46. James, A.M.; Burdett, C.; McCool, M.J.; Fox, A.; Riggs, P. The geographic distribution and ecological preferences of the American dog tick, Dermacentor variabilis (Say), in the U.S.A. Med. Vet. Entomol. 2015, 29, 178-188. [CrossRef]

47. Monzon, J.D.; Atkinson, E.G.; Henn, B.M.; Benach, J.L. Population and Evolutionary Genomics of Amblyomma americanum, an Expanding Arthropod Disease Vector. Genome Biol. Evol. 2016, 8, 1351-1360. [CrossRef]

48. Kollars, T.M., Jr.; Oliver, J.H., Jr.; Durden, L.A.; Kollars, P.G. Host association and seasonal activity of Amblyomma americanum (Acari: Ixodidae) in Missouri. J. Parasitol. 2000, 86, 1156-1159. [CrossRef]

49. Calhoun, E.L. Natural occurrence of tularemia in the lone star tick, Amblyomma americanus (Linn.), and in dogs in Arkansas. Am. J. Trop. Med. Hyg. 1954, 3, 360-366. [CrossRef]

50. Whitten, T.; Demontigny, C.; Bjork, J.; Foss, M.; Peterson, M.; Scheftel, J.; Neitzel, D.; Sullivan, M.; Smith, K. Prevalence of Francisella tularensis in Dermacentor variabilis Ticks, Minnesota, 2017. Vector Borne Zoonotic Dis. 2019, 19, 596-603. [CrossRef]

51. Dykstra, E.A.; Oltean, H.N.; Kangiser, D.; Marsden-Haug, N.; Rich, S.M.; Xu, G.; Lee, M.K.; Morshed, M.G.; Graham, C.B.; Eisen, R.J. Ecology and Epidemiology of Tickborne Pathogens, Washington, USA, 2011-2016. Emerg. Infect. Dis. 2020, 26, 648-657. [CrossRef]

52. McCoy, G. A plague-like disease of rodents. Public Health Bull. 1911, 19, 61-72.

53. Jellison, W.L. Tularemia; geographical distribution of deerfly fever and the biting fly, Chrysops discalis Williston. Public Health Rep. 1950, 65, 1321-1329. [CrossRef]

54. Vonkavaara, M.; Telepnev, M.V.; Ryden, P.; Sjostedt, A.; Stoven, S. Drosophila melanogaster as a model for elucidating the pathogenicity of Francisella tularensis. Cell. Microbiol. 2008, 10, 1327-1338. [CrossRef]

55. Murfin, K.E.; Kleinbard, R.; Aydin, M.; Salazar, S.A.; Fikrig, E. Borrelia burgdorferi chemotaxis toward tick protein Salp12 contributes to acquisition. Ticks Tick Borne Dis. 2019, 10, 1124-1134. [CrossRef]

56. Galletti, M.F.; Fujita, A.; Rosa, R.D.; Martins, L.A.; Soares, H.S.; Labruna, M.B.; Daffre, S.; Fogaca, A.C. Virulence genes of Rickettsia rickettsii are differentially modulated by either temperature upshift or blood-feeding in tick midgut and salivary glands. Parasites Vectors 2016, 9, 331. [CrossRef]

57. Keim, P.; Johansson, A.; Wagner, D.M. Molecular epidemiology, evolution, and ecology of Francisella. Ann. N. Y. Acad. Sci. 2007, 1105, 30-66. [CrossRef]

58. Brooks, C.S.; Hefty, P.S.; Jolliff, S.E.; Akins, D.R. Global analysis of Borrelia burgdorferi genes regulated by mammalian host-specific signals. Infect. Immun. 2003, 71, 3371-3383. [CrossRef]

59. Carroll, J.A.; Cordova, R.M.; Garon, C.F. Identification of $11 \mathrm{pH}$-regulated genes in Borrelia burgdorferi localizing to linear plasmids. Infect. Immun. 2000, 68, 6677-6684. [CrossRef]

60. Yang, X.F.; Pal, U.; Alani, S.M.; Fikrig, E.; Norgard, M.V. Essential role for OspA/B in the life cycle of the Lyme disease spirochete. J. Exp. Med. 2004, 199, 641-648. [CrossRef]

61. Pal, U.; Li, X.; Wang, T.; Montgomery, R.R.; Ramamoorthi, N.; Desilva, A.M.; Bao, F.; Yang, X.; Pypaert, M.; Pradhan, D.; et al. TROSPA, an Ixodes scapularis receptor for Borrelia burgdorferi. Cell 2004, 119, 457-468. [CrossRef]

62. Yang, X.; Goldberg, M.S.; Popova, T.G.; Schoeler, G.B.; Wikel, S.K.; Hagman, K.E.; Norgard, M.V. Interdependence of environmental factors influencing reciprocal patterns of gene expression in virulent Borrelia burgdorferi. Mol. Microbiol. 2000, 37, 1470-1479. [CrossRef] [PubMed]

63. Celli, J.; Zahrt, T.C. Mechanisms of Francisella tularensis intracellular pathogenesis. Cold Spring Harb. Perspect. Med. 2013, 3, a010314. [CrossRef] [PubMed]

64. Steiner, D.J.; Furuya, Y.; Jordan, M.B.; Metzger, D.W. Protective Role for Macrophages in Respiratory Francisella tularensis Infection. Infect. Immun. 2017, 85. [CrossRef] [PubMed]

65. Canton, J.; Khezri, R.; Glogauer, M.; Grinstein, S. Contrasting phagosome pH regulation and maturation in human M1 and M2 macrophages. Mol. Biol. Cell. 2014, 25, 3330-3341. [CrossRef]

66. KuoLee, R.; Zhao, X.; Austin, J.; Harris, G.; Conlan, J.W.; Chen, W. Mouse model of oral infection with virulent type A Francisella tularensis. Infect. Immun. 2007, 75, 1651-1660. [CrossRef]

67. Fuller, J.R.; Kijek, T.M.; Taft-Benz, S.; Kawula, T.H. Environmental and intracellular regulation of Francisella tularensis ripA. BMC Microbiol. 2009, 9, 216. [CrossRef]

68. Chong, A.; Wehrly, T.D.; Nair, V.; Fischer, E.R.; Barker, J.R.; Klose, K.E.; Celli, J. The early phagosomal stage of Francisella tularensis determines optimal phagosomal escape and Francisella pathogenicity island protein expression. Infect. Immun. 2008, 76, 5488-5499. [CrossRef] 
69. Pan, X.; Tamilselvam, B.; Hansen, E.J.; Daefler, S. Modulation of iron homeostasis in macrophages by bacterial intracellular pathogens. BMC Microbiol. 2010, 10, 64. [CrossRef]

70. Ouyang, Z.; Deka, R.K.; Norgard, M.V. BosR (BB0647) controls the RpoN-RpoS regulatory pathway and virulence expression in Borrelia burgdorferi by a novel DNA-binding mechanism. Plos Pathog. 2011, 7, e1001272. [CrossRef]

71. Deng, K.; Blick, R.J.; Liu, W.; Hansen, E.J. Identification of Francisella tularensis genes affected by iron limitation. Infect. Immun. 2006, 74, 4224-4236. [CrossRef]

72. Horzempa, J.; Carlson, P.E., Jr.; O’Dee, D.M.; Shanks, R.M.; Nau, G.J. Global transcriptional response to mammalian temperature provides new insight into Francisella tularensis pathogenesis. BMC Microbiol. 2008, 8, 172. [CrossRef]

73. Li, Y.; Powell, D.A.; Shaffer, S.A.; Rasko, D.A.; Pelletier, M.R.; Leszyk, J.D.; Scott, A.J.; Masoudi, A.; Goodlett, D.R.; Wang, X.; et al. LPS remodeling is an evolved survival strategy for bacteria. Proc. Natl. Acad. Sci. USA 2012, 109, 8716-8721. [CrossRef] [PubMed]

74. Connat, J.L. Demonstration of regurgitation of gut content during blood meals of the tick Ornithodoros moubata. Possible role in the transmission of pathogenic agents. Parasitol. Res. 1991, 77, 452-454. [CrossRef]

75. Sojka, D.; Franta, Z.; Horn, M.; Caffrey, C.R.; Mares, M.; Kopacek, P. New insights into the machinery of blood digestion by ticks. Trends Parasitol. 2013, 29, 276-285. [CrossRef]

76. Meibom, K.L.; Charbit, A. Francisella tularensis metabolism and its relation to virulence. Front. Microbiol. 2010, 1, 140. [CrossRef] [PubMed]

77. Papanikolaou, G.; Pantopoulos, K. Iron metabolism and toxicity. Toxicol. Appl. Pharmacol. 2005, 202, $199-211$. [CrossRef]

78. Mohapatra, N.P.; Soni, S.; Rajaram, M.V.; Strandberg, K.L.; Gunn, J.S. Type A Francisella tularensis acid phosphatases contribute to pathogenesis. PLOS ONE 2013, 8, e56834. [CrossRef] [PubMed]

79. Ren, G.; Champion, M.M.; Huntley, J.F. Identification of disulfide bond isomerase substrates reveals bacterial virulence factors. Mol. Microbiol. 2014, 94, 926-944. [CrossRef] [PubMed]

80. Wang, J.; Bian, G.; Pan, W.; Feng, T.; Dai, J. Molecular characterization of a defensin gene from a hard tick, Dermacentor silvarum. Parasites Vectors 2015, 8, 25. [CrossRef]

81. Martins, L.A.; Malossi, C.D.; Galletti, M.; Ribeiro, J.M.; Fujita, A.; Esteves, E.; Costa, F.B.; Labruna, M.B.; Daffre, S.; Fogaca, A.C. The Transcriptome of the Salivary Glands of Amblyomma aureolatum Reveals the Antimicrobial Peptide Microplusin as an Important Factor for the Tick Protection Against Rickettsia rickettsii Infection. Front. Physiol. 2019, 10, 529. [CrossRef]

82. Galay, R.L.; Umemiya-Shirafuji, R.; Mochizuki, M.; Fujisaki, K.; Tanaka, T. Iron metabolism in hard ticks (Acari: Ixodidae): The antidote to their toxic diet. Parasitol. Int. 2015, 64, 182-189. [CrossRef] [PubMed]

83. Zolnik, C.P.; Falco, R.C.; Daniels, T.J.; Kolokotronis, S.O. Transient influence of blood meal and natural environment on blacklegged tick bacterial communities. Ticks Tick Borne Dis. 2018, 9, 563-572. [CrossRef] [PubMed]

84. Mani, R.J.; Reichard, M.V.; Morton, R.J.; Kocan, K.M.; Clinkenbeard, K.D. Biology of Francisella tularensis subspecies holarctica live vaccine strain in the tick vector Dermacentor Variabilis. PloS ONE 2012, 7, e35441. [CrossRef] [PubMed]

85. Alhede, M.; Bjarnsholt, T.; Givskov, M.; Alhede, M. Pseudomonas aeruginosa biofilms: Mechanisms of immune evasion. Adv. Appl. Microbiol. 2014, 86, 1-40. [CrossRef]

86. Guilhen, C.; Miquel, S.; Charbonnel, N.; Joseph, L.; Carrier, G.; Forestier, C.; Balestrino, D. Colonization and immune modulation properties of Klebsiella pneumoniae biofilm-dispersed cells. Npj Biofilms Microbiomes 2019, 5, 25. [CrossRef]

87. Abdel-Nour, M.; Duncan, C.; Low, D.E.; Guyard, C. Biofilms: The stronghold of Legionella pneumophila. Int. J. Mol. Sci. 2013, 14, 21660-21675. [CrossRef]

88. Lutz, C.; Erken, M.; Noorian, P.; Sun, S.; McDougald, D. Environmental reservoirs and mechanisms of persistence of Vibrio cholerae. Front. Microbiol. 2013, 4, 375. [CrossRef]

89. Jarrett, C.O.; Deak, E.; Isherwood, K.E.; Oyston, P.C.; Fischer, E.R.; Whitney, A.R.; Kobayashi, S.D.; DeLeo, F.R.; Hinnebusch, B.J. Transmission of Yersinia pestis from an infectious biofilm in the flea vector. J. Infect. Dis. 2004, 190, 783-792. [CrossRef]

90. Telford, S.R., III; Goethert, H.K. Toward an understanding of the perpetuation of the agent of tularemia. Front. Microbiol. 2010, 1, 150. [CrossRef] 
91. Dergousoff, S.J.; Anstead, C.A.; Chilton, N.B. Identification of bacteria in the Rocky Mountain wood tick, Dermacentor andersoni, using single-strand conformation polymorphism (SSCP) and DNA sequencing. Exp. Appl. Acarol. 2020, 80, 247-256. [CrossRef]

92. Merzendorfer, H.; Zimoch, L. Chitin metabolism in insects: Structure, function and regulation of chitin synthases and chitinases. J. Exp. Biol. 2003, 206, 4393-4412. [CrossRef] [PubMed]

93. Margolis, J.J.; El-Etr, S.; Joubert, L.M.; Moore, E.; Robison, R.; Rasley, A.; Spormann, A.M.; Monack, D.M. Contributions of Francisella tularensis subsp. novicida chitinases and Sec secretion system to biofilm formation on chitin. Appl. Environ. Microbiol. 2010, 76, 596-608. [CrossRef] [PubMed]

94. Durham-Colleran, M.W.; Verhoeven, A.B.; van Hoek, M.L. Francisella novicida forms in vitro biofilms mediated by an orphan response regulator. Microb. Ecol. 2010, 59, 457-465. [CrossRef] [PubMed]

95. Zogaj, X.; Wyatt, G.C.; Klose, K.E. Cyclic di-GMP stimulates biofilm formation and inhibits virulence of Francisella novicida. Infect. Immun. 2012, 80, 4239-4247. [CrossRef]

96. Champion, A.E.; Catanzaro, K.C.F.; Bandara, A.B.; Inzana, T.J. Formation of the Francisella tularensis Biofilm is Affected by Cell Surface Glycosylation, Growth Medium, and a Glucan Exopolysaccharide. Sci. Rep. 2019, 9, 12252. [CrossRef]

97. Chung, M.C.; Dean, S.; Marakasova, E.S.; Nwabueze, A.O.; van Hoek, M.L. Chitinases are negative regulators of Francisella novicida biofilms. PLoS ONE 2014, 9, e93119. [CrossRef]

98. Tilly, K.; Elias, A.F.; Errett, J.; Fischer, E.; Iyer, R.; Schwartz, I.; Bono, J.L.; Rosa, P. Genetics and regulation of chitobiose utilization in Borrelia burgdorferi. J. Bacteriol. 2001, 183, 5544-5553. [CrossRef]

99. Gall, C.A.; Reif, K.E.; Scoles, G.A.; Mason, K.L.; Mousel, M.; Noh, S.M.; Brayton, K.A. The bacterial microbiome of Dermacentor andersoni ticks influences pathogen susceptibility. ISME J. 2016, 10, 1846-1855. [CrossRef]

100. Gerhart, J.G.; Moses, A.S.; Raghavan, R. A Francisella-like endosymbiont in the Gulf Coast tick evolved from a mammalian pathogen. Sci. Rep. 2016, 6, 33670. [CrossRef]

101. Brinkerhoff, R.J.; Clark, C.; Ocasio, K.; Gauthier, D.T.; Hynes, W.L. Factors affecting the microbiome of Ixodes scapularis and Amblyomma americanum. PLoS ONE 2020, 15, e0232398. [CrossRef]

102. Trout Fryxell, R.T.; DeBruyn, J.M. The Microbiome of Ehrlichia-Infected and Uninfected Lone Star Ticks (Amblyomma americanum). PLoS ONE 2016, 11, e0146651. [CrossRef]

103. Lado, P.; Luan, B.; Allerdice, M.E.J.; Paddock, C.D.; Karpathy, S.E.; Klompen, H. Integrating population genetic structure, microbiome, and pathogens presence data in Dermacentor variabilis. PeerJ 2020, 8, e9367. [CrossRef] [PubMed]

104. Clay, K.; Klyachko, O.; Grindle, N.; Civitello, D.; Oleske, D.; Fuqua, C. Microbial communities and interactions in the lone star tick, Amblyomma americanum. Mol. Ecol. 2008, 17, 4371-4381. [CrossRef] [PubMed]

105. Wang, Y.; Mao, L.; Sun, Y.; Wang, Z.; Zhang, J.; Zhang, J.; Peng, Y.; Xia, L. A Novel Francisella-Like Endosymbiont in Haemaphysalis longicornis and Hyalomma asiaticum, China. Vector Borne Zoonotic Dis. 2018, 18, 669-676. [CrossRef] [PubMed]

106. Pavanelo, D.B.; Schroder, N.C.H.; Pin Viso, N.D.; Martins, L.A.; Malossi, C.D.; Galletti, M.; Labruna, M.B.; Daffre, S.; Farber, M.; Fogaca, A.C. Comparative analysis of the midgut microbiota of two natural tick vectors of Rickettsia rickettsii. Dev. Comp. Immunol. 2020, 106, 103606. [CrossRef] [PubMed]

107. Rynkiewicz, E.C.; Hemmerich, C.; Rusch, D.B.; Fuqua, C.; Clay, K. Concordance of bacterial communities of two tick species and blood of their shared rodent host. Mol. Ecol. 2015, 24, 2566-2579. [CrossRef]

108. Clow, K.M.; Weese, J.S.; Rousseau, J.; Jardine, C.M. Microbiota of field-collected Ixodes scapularis and Dermacentor variabilis from eastern and southern Ontario, Canada. Ticks Tick Borne Dis. 2018, 9, 235-244. [CrossRef] [PubMed]

109. Kaufman, E.L.; Stone, N.E.; Scoles, G.A.; Hepp, C.M.; Busch, J.D.; Wagner, D.M. Range-wide genetic analysis of Dermacentor variabilis and its Francisella-like endosymbionts demonstrates phylogeographic concordance between both taxa. Parasit. Vectors 2018, 11, 306. [CrossRef]

110. Macaluso, K.R.; Sonenshine, D.E.; Ceraul, S.M.; Azad, A.F. Rickettsial infection in Dermacentor variabilis (Acari: Ixodidae) inhibits transovarial transmission of a second Rickettsia. J. Med. Entomol. 2002, 39, 809-813. [CrossRef]

111. Mohanty, I.; Rath, A.; Swain, S.P.; Pradhan, N.; Hazra, R.K. Wolbachia Population in Vectors and Non-vectors: A Sustainable Approach Towards Dengue Control. Curr. Microbiol. 2019, 76, 133-143. [CrossRef] 
112. Rivas, J.J.; Moreira-Soto, A.; Alvarado, G.; Taylor, L.; Calderon-Arguedas, O.; Hun, L.; Corrales-Aguilar, E.; Morales, J.A.; Troyo, A. Pathogenic potential of a Costa Rican strain of 'Candidatus Rickettsia amblyommii' in guinea pigs (Cavia porcellus) and protective immunity against Rickettsia rickettsii. Ticks Tick Borne Dis. 2015, 6, 805-811. [CrossRef] [PubMed]

113. Billeter, S.A.; Blanton, H.L.; Little, S.E.; Levy, M.G.; Breitschwerdt, E.B. Detection of Rickettsia amblyommii in association with a tick bite rash. Vector Borne Zoonotic Dis. 2007, 7, 607-610. [CrossRef] [PubMed]

114. Hajdusek, O.; Sima, R.; Ayllon, N.; Jalovecka, M.; Perner, J.; de la Fuente, J.; Kopacek, P. Interaction of the tick immune system with transmitted pathogens. Front. Cell. Infect. Microbiol. 2013, 3, 26. [CrossRef]

115. Hernandez, E.P.; Talactac, M.R.; Fujisaki, K.; Tanaka, T. The case for oxidative stress molecule involvement in the tick-pathogen interactions-an omics approach. Dev. Comp. Immunol. 2019, 100, 103409. [CrossRef] [PubMed]

116. Sonenshine, D.E.; Hynes, W.L. Molecular characterization and related aspects of the innate immune response in ticks. Front. Biosci. 2008, 13, 7046-7063. [CrossRef] [PubMed]

117. Johns, R.; Sonenshine, D.E.; Hynes, W.L. Control of bacterial infections in the hard tick Dermacentor variabilis (Acari: Ixodidae): Evidence for the existence of antimicrobial proteins in tick hemolymph. J. Med. Entomol. 1998, 35, 458-464. [CrossRef] [PubMed]

118. Ceraul, S.M.; Sonenshine, D.E.; Hynes, W.L. Resistance of the tick dermacentor variabilis (Acari: Ixodidae) following challenge with the bacterium Escherichia coli (Enterobacteriales: Enterobacteriaceae). J. Med. Entomol. 2002, 39, 376-383. [CrossRef]

119. Eggenberger, L.R.; Lamoreaux, W.J.; Coons, L.B. Hemocytic encapsulation of implants in the tick Dermacentor variabilis. Exp. Appl. Acarol. 1990, 9, 279-287. [CrossRef]

120. Mambie, A.; Wallet, F.; Scherman, L.; Armand, S.; Vervelle, C.; Faure, K.; Guery, B.; Titecat, M.; Loiez, C. Neither Neoplasia nor Tuberculosis, but Francisella. Open Forum Infect. Dis. 2016, 3, ofw080. [CrossRef] [PubMed]

121. Bokhari, S.M.; Kim, K.J.; Pinson, D.M.; Slusser, J.; Yeh, H.W.; Parmely, M.J. NK cells and gamma interferon coordinate the formation and function of hepatic granulomas in mice infected with the Francisella tularensis live vaccine strain. Infect. Immun. 2008, 76, 1379-1389. [CrossRef] [PubMed]

122. Rasmussen, J.W.; Cello, J.; Gil, H.; Forestal, C.A.; Furie, M.B.; Thanassi, D.G.; Benach, J.L. Mac-1+ cells are the predominant subset in the early hepatic lesions of mice infected with Francisella tularensis. Infect. Immun. 2006, 74, 6590-6598. [CrossRef]

123. Johns, R.; Sonenshine, D.E.; Hynes, W.L. Response of the tick Dermacentor variabilis (Acari: Ixodidae) to hemocoelic inoculation of Borrelia burgdorferi (Spirochetales). J. Med. Entomol. 2000, 37, 265-270. [CrossRef] [PubMed]

124. Liu, L.; Narasimhan, S.; Dai, J.; Zhang, L.; Cheng, G.; Fikrig, E. Ixodes scapularis salivary gland protein P11 facilitates migration of Anaplasma phagocytophilum from the tick gut to salivary glands. EMBO Rep. 2011, 12, 1196-1203. [CrossRef] [PubMed]

125. Goddard, J. Experimental infection of lone star ticks, Amblyomma americanum (L.), with Rickettsia parkeri and exposure of guinea pigs to the agent. J. Med. Entomol. 2003, 40, 686-689. [CrossRef]

126. Jones, C.L.; Napier, B.A.; Sampson, T.R.; Llewellyn, A.C.; Schroeder, M.R.; Weiss, D.S. Subversion of host recognition and defense systems by Francisella spp. Microbiol. Mol. Biol. Rev. 2012, 76, 383-404. [CrossRef] [PubMed]

127. Steiner, D.J.; Furuya, Y.; Metzger, D.W. Detrimental Influence of Alveolar Macrophages on Protective Humoral Immunity during Francisella tularensis SchuS4 Pulmonary Infection. Infect. Immun. 2018, 86, e00787-17. [CrossRef] [PubMed]

128. Gulia-Nuss, M.; Nuss, A.B.; Meyer, J.M.; Sonenshine, D.E.; Roe, R.M.; Waterhouse, R.M.; Sattelle, D.B.; de la Fuente, J.; Ribeiro, J.M.; Megy, K.; et al. Genomic insights into the Ixodes scapularis tick vector of Lyme disease. Nat. Commun. 2016, 7, 10507. [CrossRef]

129. Wang, Y.; Zhu, S. The defensin gene family expansion in the tick Ixodes scapularis. Dev. Comp. Immunol. 2011, 35, 1128-1134. [CrossRef]

130. Ceraul, S.M.; Dreher-Lesnick, S.M.; Gillespie, J.J.; Rahman, M.S.; Azad, A.F. New tick defensin isoform and antimicrobial gene expression in response to Rickettsia montanensis challenge. Infect. Immun. 2007, 75, 1973-1983. [CrossRef] 
131. Ceraul, S.M.; Dreher-Lesnick, S.M.; Mulenga, A.; Rahman, M.S.; Azad, A.F. Functional characterization and novel rickettsiostatic effects of a Kunitz-type serine protease inhibitor from the tick Dermacentor variabilis. Infect. Immun. 2008, 76, 5429-5435. [CrossRef] [PubMed]

132. Ceraul, S.M.; Chung, A.; Sears, K.T.; Popov, V.L.; Beier-Sexton, M.; Rahman, M.S.; Azad, A.F. A Kunitz protease inhibitor from Dermacentor variabilis, a vector for spotted fever group rickettsiae, limits Rickettsia montanensis invasion. Infect. Immun. 2011, 79, 321-329. [CrossRef] [PubMed]

133. Johns, R.; Sonenshine, D.E.; Hynes, W.L. Identification of a defensin from the hemolymph of the American dog tick, Dermacentor variabilis. Insect. Biochem. Mol. Biol. 2001, 31, 857-865. [CrossRef]

134. Kocan, K.M.; de la Fuente, J.; Manzano-Roman, R.; Naranjo, V.; Hynes, W.L.; Sonenshine, D.E. Silencing expression of the defensin, varisin, in male Dermacentor variabilis by RNA interference results in reduced Anaplasma marginale infections. Exp. Appl. Acarol. 2008, 46, 17-28. [CrossRef]

135. Kocan, K.M.; Zivkovic, Z.; Blouin, E.F.; Naranjo, V.; Almazan, C.; Mitra, R.; de la Fuente, J. Silencing of genes involved in Anaplasma marginale-tick interactions affects the pathogen developmental cycle in Dermacentor variabilis. BMC Dev. Biol. 2009, 9, 42. [CrossRef] [PubMed]

136. Kim, T.K.; Tirloni, L.; Pinto, A.F.M.; Diedrich, J.K.; Moresco, J.J.; Yates, J.R., III; da Silva Vaz, I., Jr.; Mulenga, A. Time-resolved proteomic profile of Amblyomma americanum tick saliva during feeding. PloS Negl. Trop. Dis. 2020, 14, e0007758. [CrossRef]

137. Larsson, P.; Oyston, P.C.; Chain, P.; Chu, M.C.; Duffield, M.; Fuxelius, H.H.; Garcia, E.; Halltorp, G.; Johansson, D.; Isherwood, K.E.; et al. The complete genome sequence of Francisella tularensis, the causative agent of tularemia. Nat. Genet. 2005, 37, 153-159. [CrossRef]

138. Caimano, M.J.; Drecktrah, D.; Kung, F.; Samuels, D.S. Interaction of the Lyme disease spirochete with its tick vector. Cell. Microbiol. 2016, 18, 919-927. [CrossRef]

139. Kung, F.; Anguita, J.; Pal, U. Borrelia burgdorferi and tick proteins supporting pathogen persistence in the vector. Future Microbiol. 2013, 8, 41-56. [CrossRef]

Publisher's Note: MDPI stays neutral with regard to jurisdictional claims in published maps and institutional affiliations.

(C) 2020 by the authors. Licensee MDPI, Basel, Switzerland. This article is an open access article distributed under the terms and conditions of the Creative Commons Attribution (CC BY) license (http://creativecommons.org/licenses/by/4.0/). 